\title{
Ocena mikrostruktury złączy spawanych stopu Inconel 617
}

\section{The assessment of welded joints microstructure for Inconel 617 alloy}

\section{Streszczenie}

W związku z przyjęciem pakietu energetyczno-klimatycznego przez kraje członkowskie Unii Europejskiej należy zwiększyć efektywność energetyczną przy zminimalizowaniu emisji gazów cieplarnianych do atmosfery. Wyższa sprawność bloków energetycznych przy zmniejszonej emisji zanieczyszczeń jest możliwa do osiągnięcia przez podwyższenie parametrów termodynamicznych pary, tj. ciśnienia i temperatury. Wymienianym kandydatem na najbardziej obciążone elementy kotła jest stop Inconel 617. W krajowej literaturze brak jest szczegółowych informacji dotyczących oceny mikrostruktury złączy spawanych z badanego stopu. Uzyskane wyniki badań w przyszłości posłużą konstruktorom i projektantom w szacowaniu trwałości złączy spawanych stopu Inconel 617.

Słowa kluczowe: mikrostruktura; Inconel 617; stopy niklu; złącza spawane

\begin{abstract}
In connection with the adoption of the energy and climate package by the member states of the European Union, it is necessary to increase energy efficiency while minimizing greenhouse gas emissions to the atmosphere. Higher efficiency of power units with reduced emission of pollutants is possible to achieve by increasing thermodynamic parameters of steam (pressure and temperature). The replaced candidate for the most loaded boiler elements is the Inconel 617 alloy. In the national literature there is no detailed information on the evaluation of the microstructure of welded joints from the tested alloy. The obtained test results in the future will be used by constructors and designers in estimating the durability of welded joints of the Inconel 617 alloy.
\end{abstract}

Keywords: microstructure; Inconel 617 alloy, nickel alloys, welded joints

\section{Wstęp}

Obecnie największym wyzwaniem dla przemysłu energetycznego jest dążenie do osiągnięcia sprawności netto bloków energetycznych wynoszącej $50 \%$. Jest to odpowiedź na restrykcyjną politykę Unii Europejskiej dotyczącą zmniejszenia emisji zanieczyszczeń do atmosfery [1].

Jednym ze sposobów zwiększenia sprawności kotłów energetycznych jest zastosowanie zaawansowanych materiałów. Dla temperatury pary wynoszącej ok. $680^{\circ} \mathrm{C}$, konwencjonalne materiały stosowane na elementy ciśnieniowe nie spełniają wymagań przemysłu ze względu na niskie właściwości mechaniczne [2]. Alternatywą mogą być nowoczesne materiały, do których należą stopy niklu. Stopy niklu to materiały żarowytrzymałe i żaroodporne o niezmiennych właściwościach w podwyższonej i wysokiej temperaturze [3]. Spośród stopów niklu umacnianych roztworowo, często proponowanym materiałem na ściany szczelne, wężownice i komory przegrzewacza pary w kotłach supernadkrytycznych jest Inconel 617. Jest to wieloskładnikowy stop należący do grupy Ni-Cr-Mo-Co i dzięki zastosowanym dodatkom stopowym, materiał charakteryzuje się wysoką wytrzymałością na pełzanie, stabilnością mikrostruktury, odpornością na korozję wysokotemperaturową oraz na utlenianie w wysokiej temperaturze $[4,5]$.
Stop został zaprojektowany w latach 60. ubiegłego wieku, jednak jego właściwości w wysokiej temperaturze zostały opisane podczas trwającego w Niemczech projektu COORETEC w 2002 r. Obecnie trwają badania, w ramach których Inconel 617 jest przewidziany na wymienniki ciepła w reaktorze jądrowym. Inconel 617 jest także wymieniany jako potencjalny materiał na turbiny gazowe oraz na elementy wyposażeniowe (np. kosze) do obróbki cieplnej [6,7].

Celem artykułu jest analiza i ocena złączy spawanych ze stopu Inconel 617 wykonanych metodą TIG. W artykule przedstawiono wyniki badań metalograficznych za pomocą mikroskopu świetlnego, skaningowego oraz transmisyjnego. Badania zostały uzupełnione mikroanalizą składu chemicznego EDS, a otrzymane wyniki zostały potwierdzone poprzez przeprowadzoną dyfrakcję elektronową złączy spawanych ze stopu Inconel 617.

\section{Materiał i metodyka badań}

Materiałem do badań były złącza doczołowe blachy o grubości 3 i $5 \mathrm{~mm}$ ze stopu Inconel 617 o składzie chemicznym

Mgr inż. Natalia Konieczna - Politechnika Śląska.

Autor korespondencyjny/Corresponding author: natalia.konieczna@polsı.pl 
podanym w tablicy I. Złącza zostały wykonane za pomocą procesu spawania elektrodą wolframową w obecności gazu obojętnego (argonu) metodą TIG. Parametry spawania zostały dobrane tak, aby uzyskać pełny przetop (tabl. II). Do spawania użyto drut spawalniczy o średnicy $2,4 \mathrm{~mm}$ w gatunku ERNiCrCoMo-1 (wg ANSI/AWS A5.14M-2010). Skład chemiczny materiału dodatkowego został przedstawiony w tablicy III.

Badania metalograficzne przeprowadzono na próbkach pobranych ze złącza spawanego ze stopu Inconel 617. Próbki zostały pobrane prostopadle do kierunku spawania tak, aby ujawnić typowe obszary złącza, tj. materiał rodzimy, strefy wpływu ciepła (SWC) oraz materiał spoiny. Zgłady metalograficzne były trawione elektrochemicznie w odczynniku Lucasa przy napięciu $6 \mathrm{~V}$ przez 15 sekund. Przykładowe wyniki obserwacji dla poszczególnych stref złącza pokazano na rysunkach $1 \div 4$. Badania metalograficzne przeprowadzono na stereoskopowym mikroskopie świetlnym Olympus SZX 9 przy powiększeniach do 50x (SM) oraz na mikroskopie świetlnym Olympus GX-71 w technice obserwacji w polu jasnym (LM). Wykonano także badania strukturalne przy dużych powiększeniach oraz mikroanalizę składu chemicznego za pomocą elektronowego mikroskopu skaningowego z przystawką EDS (Hitachi S3400N) (SEM) (rys. 5). Badania zostały uzupełnione obserwacjami substruktury prowadzonymi za pomocą skaningowo-transmisyjnego mikroskopu (STEM) HD-2300 A firmy HITACHI (rys. 6, rys. 7).

\section{Wyniki i ich dyskusja}

Analiza wyników badań wizualnych wykonanych zgodnie z wymaganiami normy PN-EN ISO 17637:2011 nie ujawniła niezgodności spawalniczych. Stwierdzono, że lico każdej ze spoin jest równomierne, bez nieciągłości i podtopień. Nie zaobserwowano również pozostałości żużla spawalniczego. Makrostruktura połączenia była prawidłowa, co potwierdza prawidłowy dobór parametrów spawania (rys. 1).

Na podstawie badań mikrostruktury za pomocą mikroskopu świetlnego stwierdzono, że materiał rodzimy złącza spawanego charakteryzuje się poligonalnymi ziarnami osnowy $Y$ z bliźniakami umacniającymi materiał. Ujawniono także wydzielenia zarówno na granicy, jak i wewnątrz ziarn (rys. 2a).
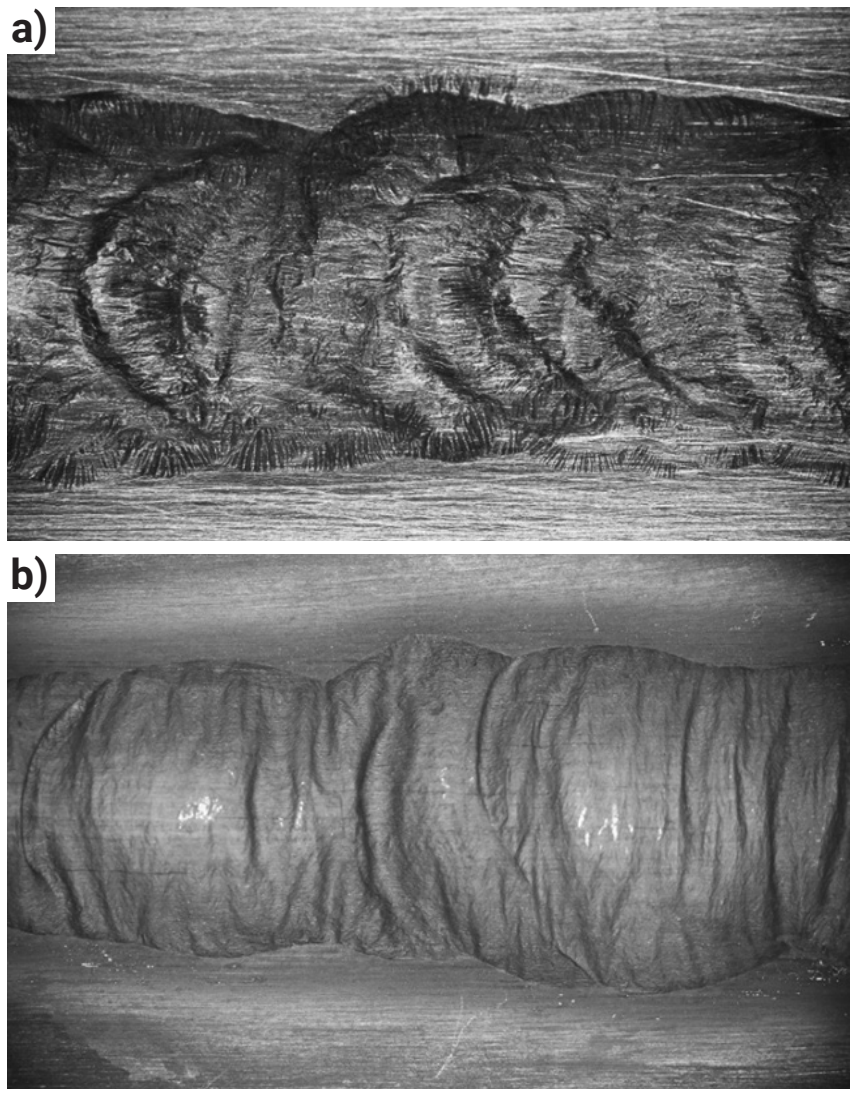

Rys. 1. Makrostruktura złącza spawanego stopu Inconel 617, SM: a) lico spoiny, b) grań spoiny

Fig. 1. The macrostructure of Inconel 617 welded joint, SM: a) weld face, $b$ ) weld ridge

Potwierdzają to również obserwacje na mikroskopie skaningowym (rys. 2b). Ujawnione wydzielenia stanowią prawdopodobnie węgliki $\mathrm{M}_{23} \mathrm{C}_{6}$, które są charakterystyczne dla tego stopu.

W obszarze strefy wpływu ciepła zaobserwowano typową strukturę dla oddziaływania cyklu cieplnego podczas spawania. Ujawniono także, że w złączu spawanym kryształy narastają na nadtopionych ziarnach tworząc linie wtopienia (rys. 3a). W tym obszarze następuje rozrost ziarn osnowy $Y$ (rys. 3a, rys. 3b).

Tablica I. Skład chemiczny stopu niklu Inconel 617, \% wag. [8]

Table I. Chemical composition of Inconel 617 alloy, \% wt. [8]

\begin{tabular}{|c|c|c|c|c|c|c|c|c|c|c|c|c|}
\hline \multicolumn{13}{|c|}{ Skład chemiczny stopu Inconel 617 wg ASME SB-168:2013 } \\
\hline $\mathrm{Ni}$ & $\mathrm{Cr}$ & Co & Mo & Al & $\mathrm{Fe}$ & Mn & Si & $\mathrm{Ti}$ & $\mathrm{Cu}$ & S & B & C \\
\hline $\begin{array}{l}\min . \\
44,5\end{array}$ & $\begin{array}{c}20,0 \\
\div 24,0\end{array}$ & $\begin{array}{c}10,0 \\
\div 15,0\end{array}$ & $\begin{array}{c} \\
\quad 8,0 \\
\div 10,0\end{array}$ & $\begin{array}{c}0,80 \\
\div 1,50\end{array}$ & $\max .3,0$ & $\max .1,0$ & $\max .1,0$ & $\max .0,6$ & $\max 0,5$ & $\begin{array}{l}\text { max. } \\
0,015\end{array}$ & $\begin{array}{l}\max . \\
0,006\end{array}$ & $\begin{array}{c}0,05 \\
\div 0,15\end{array}$ \\
\hline
\end{tabular}

Tablica II. Parametry spawania stopu Inconel 617 metodą TIG

Table II. The welding parameters for Inconel 617 alloy done by TIG method

\begin{tabular}{|c|c|c|c|c|}
\hline Grubość płyty, $\mathbf{m m}$ & Natężenie prądu, A & Napięcie prądu, $\mathbf{V}$ & $\begin{array}{c}\text { Prędkość spawania, } \\
\mathbf{m m} / \mathbf{s}\end{array}$ & $\begin{array}{c}\text { Energia liniowa spawa- } \\
\text { nia, kJ/mm }\end{array}$ \\
\cline { 1 - 2 } 3 & 85 & 25 & 1,2 & 1,06 \\
\hline 5 & 140 & & 1,75 \\
\hline
\end{tabular}

Tablica III. Skład chemiczny drutu spawalniczego do spawania stopu Inconel 617 metodą TIG

Table III. The chemical composition of welding wire for welding Inconel 617 alloy

\begin{tabular}{|c|c|c|c|c|c|c|c|c|c|c|c|c|}
\hline \multicolumn{10}{|c|}{ Drut spawalniczy ERNiCrCoMo-1 wg ANSI/AWS A5.14M-2010 } \\
\hline $\mathbf{C}$ & $\mathbf{S i}$ & $\mathbf{M n}$ & $\mathbf{P}$ & $\mathbf{S}$ & $\mathbf{A l}$ & $\mathbf{C o}$ & $\mathbf{C r}$ & $\mathbf{C u}$ & $\mathbf{F e}$ & $\mathbf{M o}$ & $\mathbf{N i}$ & $\mathbf{T i}$ \\
\hline 0,084 & 0,03 & 0,05 & 0,004 & 0.001 & 1,16 & 11,60 & 22,50 & 0,02 & 1,00 & 9,10 & 54,00 & 0,34 \\
\hline
\end{tabular}



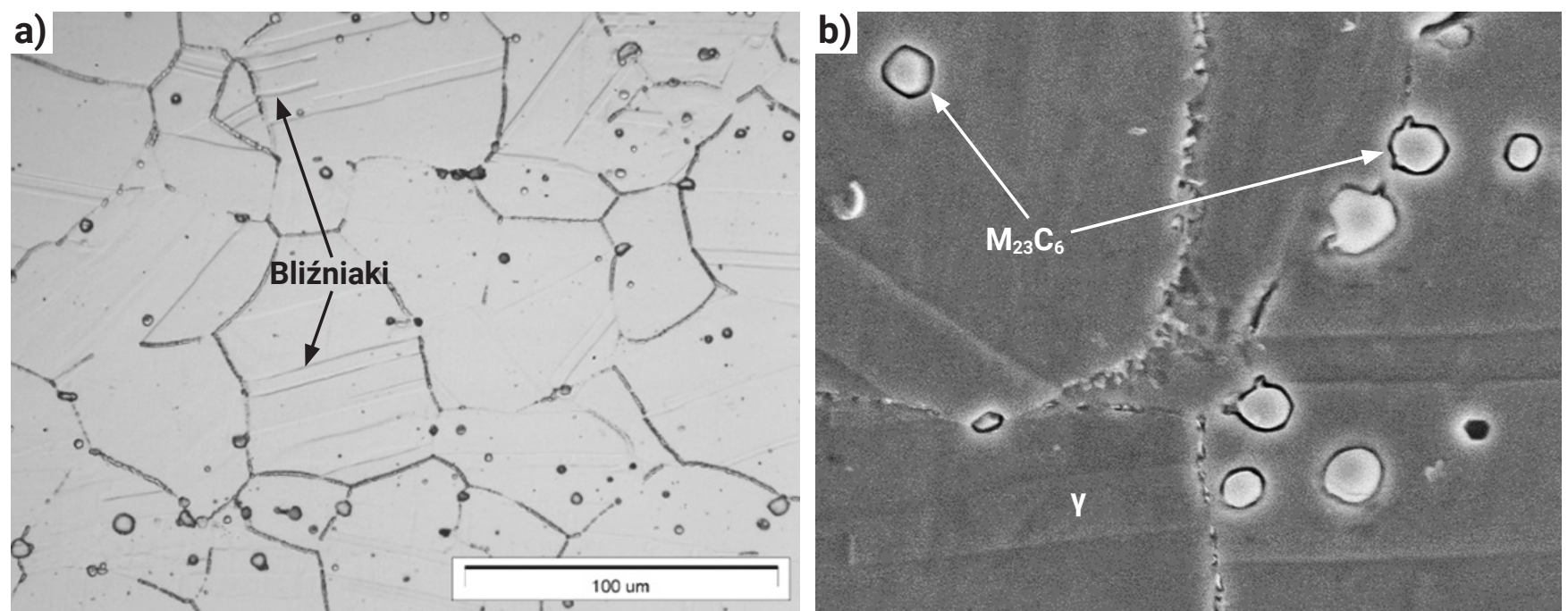

Rys. 2. Mikrostruktura materiału rodzimego stopu Inconel 617: a) poligonalne ziarna osnowy y, LM; b) globularne wydzielenia faz wewnątrz ziarna oraz płytkowe wydzielenia na granicy, pow. 5000x, SEM

Fig. 2. The microstructure of Inconel 617 native material: a) polygonal grains of matrix $y, L M ; b)$ globular phases precipitation inside the grain and lamellar precipitation at the boundaries
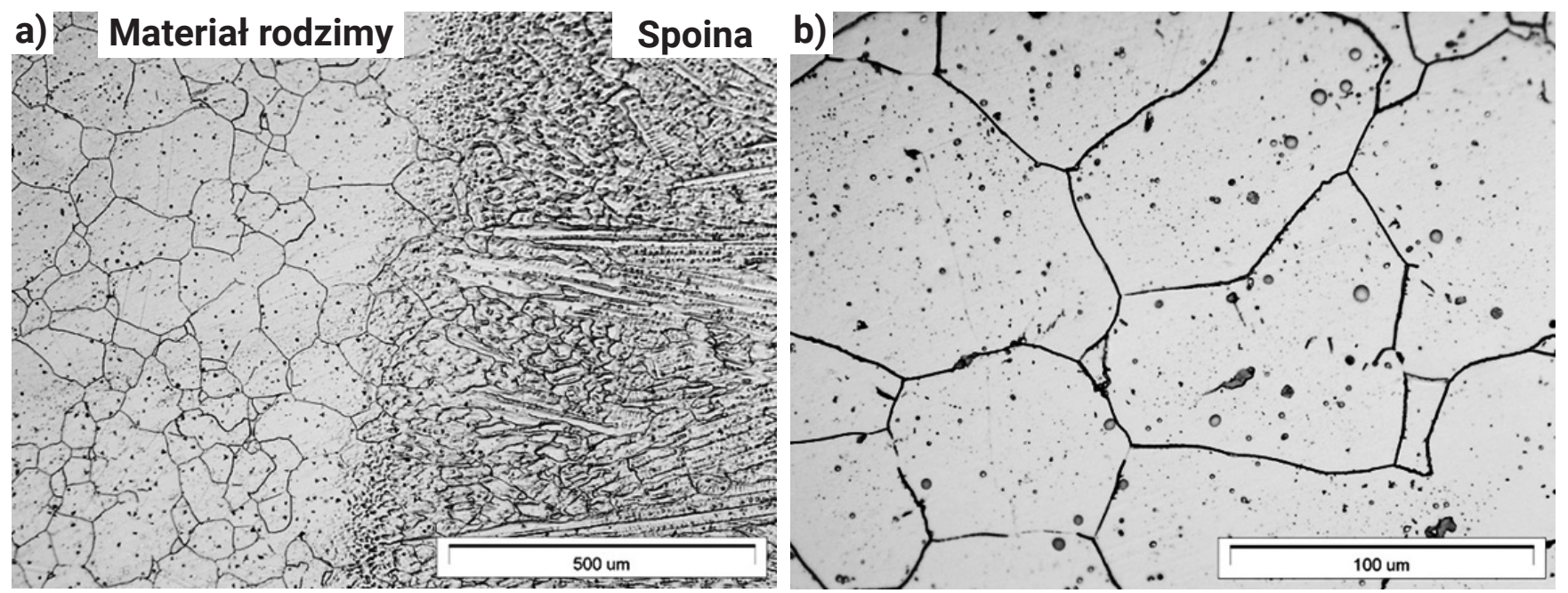

Rys. 3. Struktura SWC złącza doczołowego, LM: a) linia wtopienia spoiny; b) rozrost ziarn osnowy y z wydzieleniami faz

Fig. 3. The structure of heat affected zone (HAZ), LM: a) the line of weld penetration; b) grain growth of the matrix y phase precipitates

Zaobserwowano, że spoina charakteryzuje się wydłużonymi krystalitami, które narastały zgodnie z kierunkiem odprowadzenia ciepła (rys. 4a). Na podstawie obserwacji przy dużych powiększeniach za pomocą skaningowo-transmisyjnego mikroskopu elektronowego stwierdzono, że substruktura charakteryzuje się dyslokacjami, które umacniają materiał (rys. 4b). Ujawniono wydzielenie, które najprawdopodobniej stanowi węglik typu $\mathrm{M}_{23} \mathrm{C}_{6}$ (rys. $4 \mathrm{~b}$ ).

Uzupełnieniem badań strukturalnych jest analiza składu chemicznego ujawnionych wydzieleń za pomocą mikroanalizy składu chemicznego EDS na mikroskopie skaningowym (rys. 5).
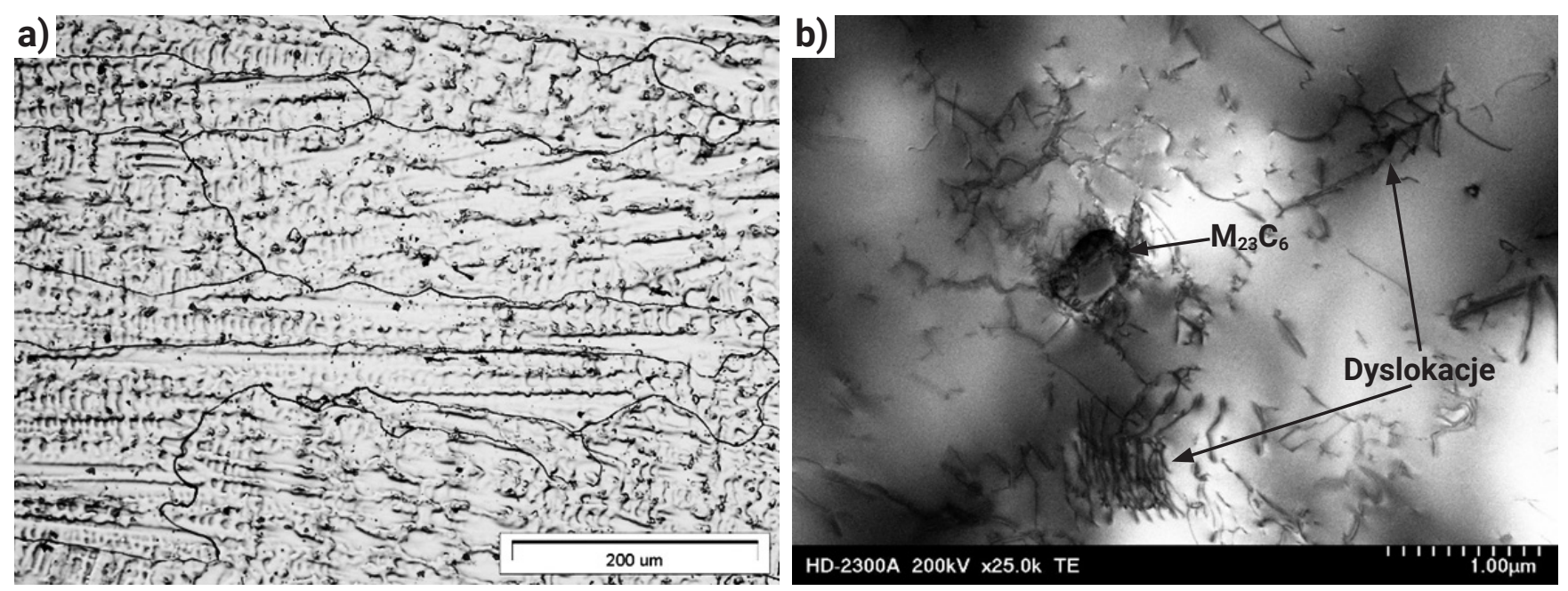

Rys. 4. Struktura spoiny stopu Inconel 617: a) wydłużone kryształy spoiny, LM; b) dyslokacje wraz z wydzieleniem w substrukturze spoiny, STEM

Fig. 4. The structure of Inconel 617 weld: a) elongated weld crystals, LM; b) dislocations with precipitates in the substructure of the weld 


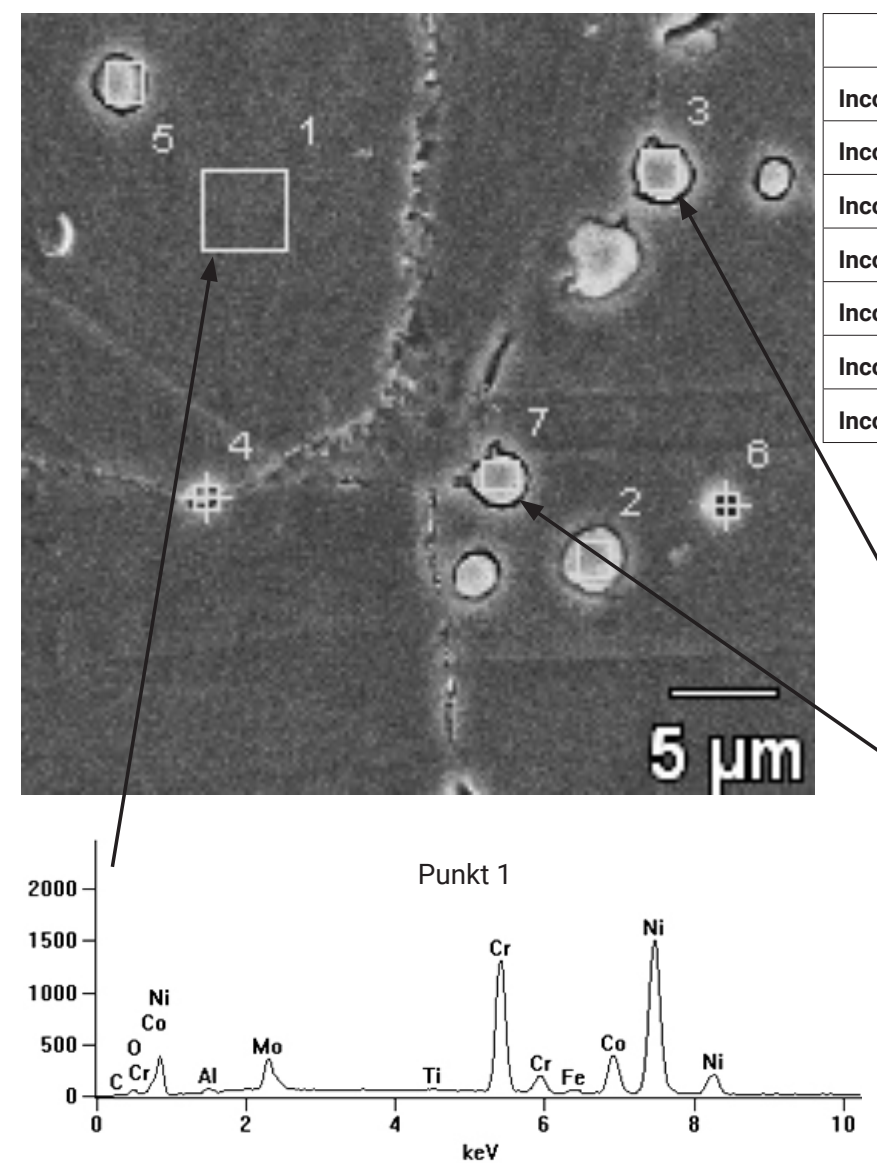

\begin{tabular}{|c|c|c|c|c|c|c|c|c|}
\hline \% wag. & Al-K & Ti-K & Cr-K & Mn-K & Fe-K & Co-K & Ni-K & Mo-L \\
\hline Inconel617_pt1 & 1,1 & 0,3 & 23,2 & & 1,0 & 11,3 & 54,5 & 8,7 \\
\hline Inconel617_pt2 & & & 57,2 & & & 5,3 & 18,4 & 19,1 \\
\hline Inconel617_pt3 & & & 59,5 & 0,1 & & 4,4 & 15,6 & 20,4 \\
\hline Inconel617_pt4 & 0,5 & 0,5 & 48,8 & 0,2 & 0,7 & 6,6 & 28,3 & 14,3 \\
\hline Inconel617_pt5 & 0,3 & & 60,7 & 0,1 & 0,5 & 4,2 & 14,5 & 19,8 \\
\hline Inconel617_pt6 & 0,3 & 0,2 & 24,4 & & 0,9 & 11,6 & 57,5 & 5,1 \\
\hline Inconel617_pt7 & & 0,3 & 55,8 & 0,0 & 0,3 & 4,9 & 17,1 & 21,5 \\
\hline
\end{tabular}

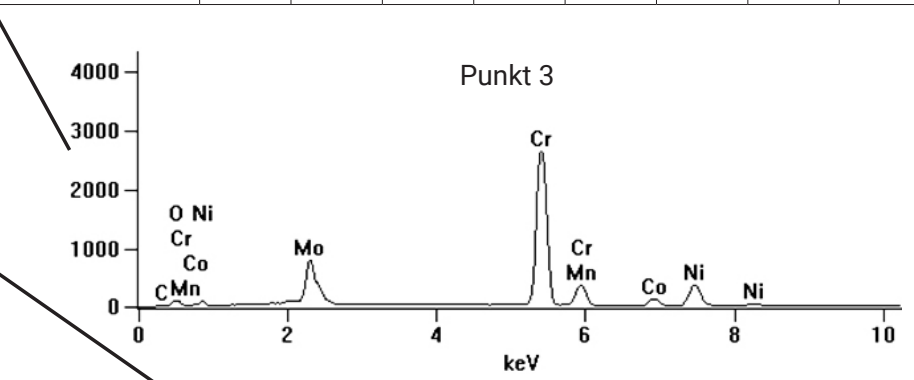

Rys. 5. Wyniki mikroanalizy składu chemicznego EDS z obszaru materiału rodzimego stopu Inconel 617

Fig. 5. The results of chemical composition EDS microanalysis from native material area of Inconel 617 alloy

Na podstawie uzyskanych wyników stwierdzono, że obecne wydzielenia $w$ materiale są złożone $z$ chromu oraz molibdenu, co może sugerować obecność wydzieleń węglików wtórnych $\mathrm{M}_{23} \mathrm{C}_{6}$. Potwierdzono także, że osnowa stopu składa się z niklu chromu, molibdenu oraz kobaltu.

Dodatkowo wykonano również szczegółową analizę za pomocą skaningowo-transmisyjnego mikroskopu elektronowego (STEM). Za pomocą tych badań ujawniono wydzielenia stopu, które zostały następnie potwierdzone za pomocą analizy elektronowej. Przykładowe wyniki badań przedstawiono na rysunku 6 i rysunku 7.

Stwierdzono, że w materiale Inconel 617 oprócz umacniających wydzieleń węglików wtórnych, obecne są również węgliko-azotki tytanu zwiększające wytrzymałość badane- go stopu (rys. 6a). W strefie wpływu ciepła zaobserwowano, że na granicy podziarn tworzą się wydzielenia $\mathrm{M}_{23} \mathrm{C}_{6}$ wpływając na dobrą odporność na pełzanie złącza spawanego (rys. 6b).

Ujawnione wydzielenia poddano identyfikacji za pomocą analizy elektronowej. Przykładowy wynik dyfrakcji przedstawiono na rysunku 7. Za pomocą analizy elektronowej potwierdzono obecność azotków tytanu, węglików pierwotnych $\mathrm{MC}$ oraz węglików wtórnych $\mathrm{M}_{23} \mathrm{C}_{6}$, które decydują o dobrych właściwościach wytrzymałościowych stopu w wysokiej temperaturze. Potwierdzono, że wydzielenia bogate w chrom i molibden stanowią wydzielenia węglików wtórnych typu $\mathrm{M}_{23} \mathrm{C}_{6}$ (rys. 7).
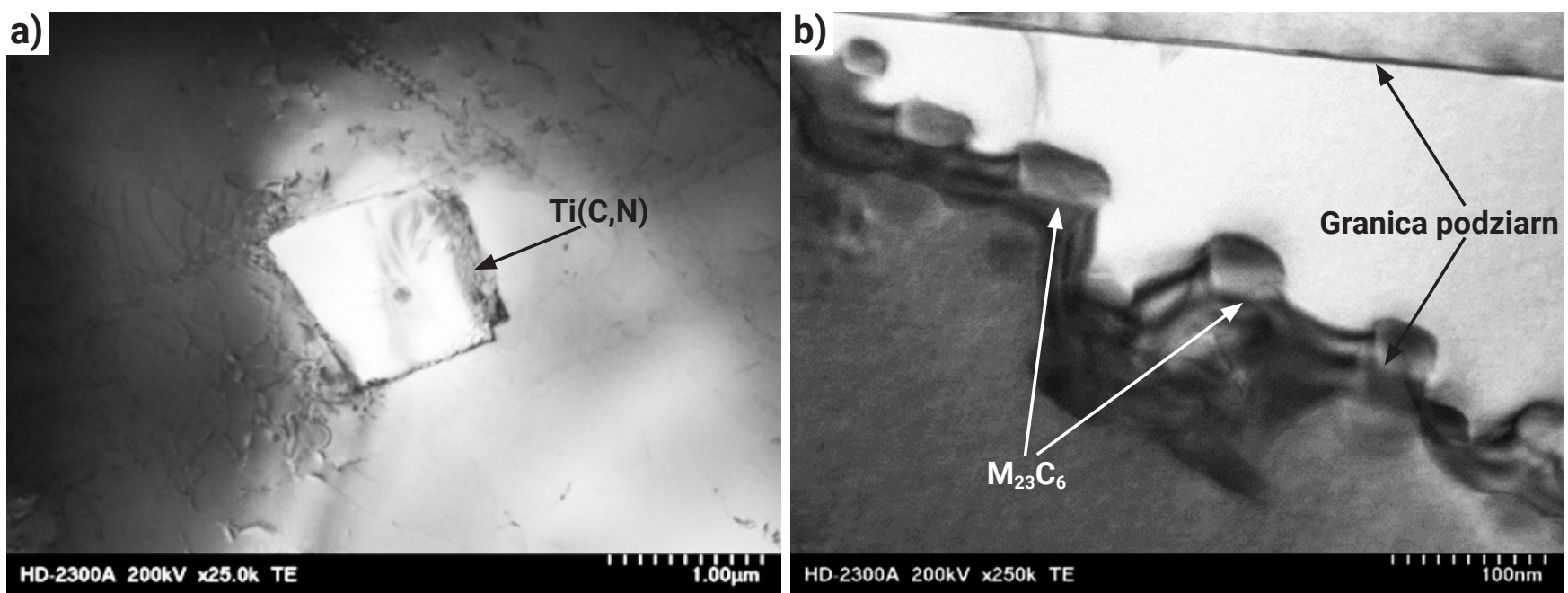

Rys. 6. Substruktura doczołowego złącza spawanego stopu Inconel 617, STEM: a) węgliko-azotka tytanu w materiale rodzimym; b) granica ziarn w SWC

Fig. 6. The substructure of Inconel 617 butt-welded joint, STEM: a) precipitation of titanium carbide-nitride in the native material; b) the grains boundaries in HAZ 

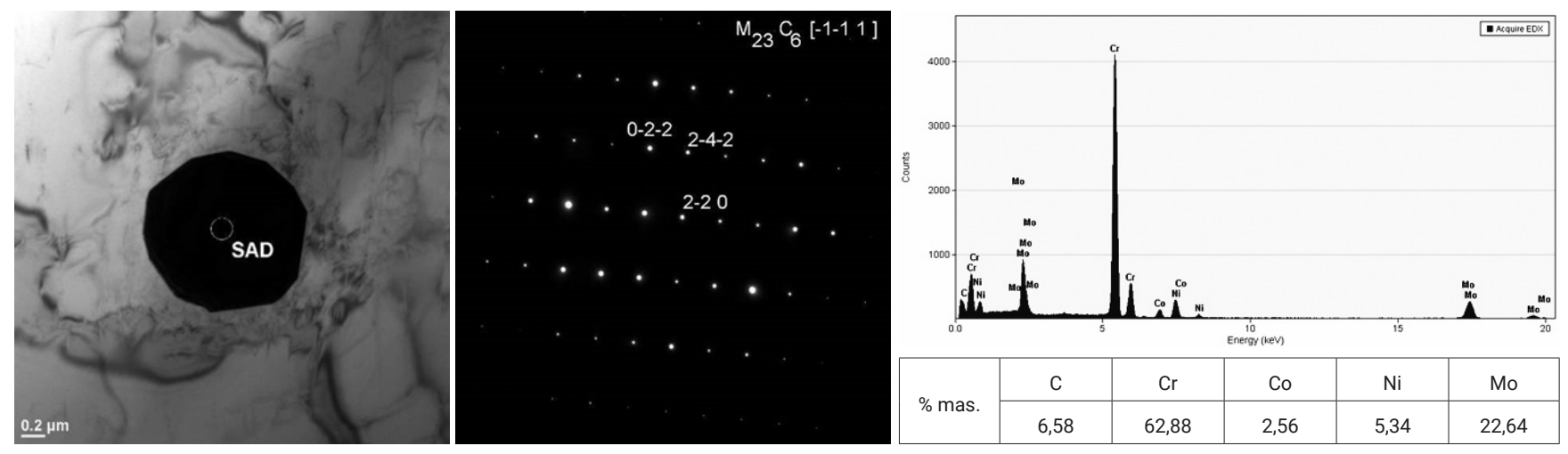

Rys. 7. Dyfrakcja elektronowa wydzielenia stopu Inconel 617, STEM

Fig. 7. Electron diffraction of precipitate in Inconel 617 alloy, STEM

\section{Wnioski}

Na podstawie przeprowadzonych badań stwierdzono, że parametry spawania stopu Inconel 617 zostały dobrane poprawnie, o czym świadczy brak niezgodności spawalniczych. Złącze spawane zostało sklasyfikowane do poziomu jakości B wg PN-EN ISO 5817.

Zaobserwowano, że najlepszą metodą trawienia złącza spawanego jest trawienie elektrochemiczne w odczynniku Lucasa przy napięciu $6 \mathrm{~V}$ i czasie $15 \mathrm{~s}$.

Materiał rodzimy stopu składa się z osnowy y złożonej głównie z Ni-Cr i dodatków kobaltu oraz molibdenu, które decydują o roztworowym umocnieniu materiału. Zaobserwowano liczne wydzielenia zarówno na granicy, jak i wewnątrz ziarn, które stanowią węgliki pierwotne $\mathrm{MC}$ i wtórne $\mathrm{M}_{23} \mathrm{C}_{6}$ decydujące o wysokich właściwościach żarowytrzymałych stopu. Ujawniono także węgliko-azotki tytanu. Wydzielenia te są zgodne z opisem stopu deklarowaną przez producenta. Kolejnym mechanizmem umocnienia ujawnionym w badaniach były bliźniaki pochodzące z procesu wytwarzania stopu.

Strefa wpływu ciepła w badanym złączu charakteryzuje się wąskim obszarem. W SWC następuje rozrost ziarn osnowy, a krystality spoiny narastają na nadtopionych ziarnach tworząc linie wtopienia. W strefie wpływu ciepła zidentyfikowano wydzielenia węglików wtórnych typu $\mathrm{M}_{23} \mathrm{C}_{6}$ tworzących się na graniach ziarn i decydujących o umocnieniu stopu.

Materiał spoiny charakteryzuje się wydłużonymi krystalitami, które narastają zgodnie z kierunkiem odprowadzenia ciepła. Na podstawie badań przy większych powiększeniach wykazano obecność dyslokacji, które zwiększają wytrzymałość materiału, a obecne wydzielenia węglików $\mathrm{M}_{23} \mathrm{C}_{6}$ decydują o żarowytrzymałości.

Uzyskane wyniki mogą być podstawą do rozpoczęcia procedury kwalifikowania technologii spawania zgodnie z wymaganiami PN EN ISO 15614-1.

\section{Literatura}

[1] Hernas A., Dobrzański J., Pasternak J., Fudali S.: Charakterystyki nowej generacji materiałów dla energetyki, Wydawnictwo Politechniki Śląskiej, Gliwice, 2015

[2] Hernas A.: Materiały do budowy kotłów na parametry nadkrytyczne, Nowa Energia, 5-6, 2013, s. 2-7.

[3] Ma L.: Identifying and Understanding Environment-Induced Crack Propagation Behavior in Solid Strengthened Ni-Based Superalloys, Project No. 09-803, University of Nevada, 2012.

[4] Tuz L., Pańcikiewicz K., Tasak E., Adamiec J.: Ocena mikrostruktury wybranych stopów niklu, Przegląd Spawalnictwa, nr 5, 2014, s. 64-67.

[5] Tuz L., Pańcikiewicz K., Tasak E., Adamiec J.: Badania skłonności do pęknięć gorących stopów niklu, nr 4, 2016, s. 162-169.
[6] Capros P., Tasios N., Marinakis A.: Very high penetration energy sources to the European electricity system in the context of model-based analysis an energy roadmap towards a low carbon EU economy by 2050, 9th International Conference on the European Energy Market, Florencja, 2012, pp. 1-8.

[7] Patel S. J., deBarbadillo J. J., Baker B. A., Gollihue R. D.: Nickel Base Superalloys for Next Generation Coal Fired AUSC Power Plants, Procedia Engineering, nr 55, 2013, pp. 246-252.

[8] Norma ASME SB-168:2013 „Specification for nickel-chromium-iron alloys (UNS N06600, N06601, N06603, N06690, N06693, N06025, and N06045) and nickel-chromium-cobalt-molybdenum alloy (UNS N06617) plate, sheet and strip". 